\title{
A Proposed Model for Student Engagement and Standards-based
}

\section{Education}

Dr. Mohammed Abdelhady Abdelsamea ${ }^{1}$

Prof. Dr. William M. Bart ${ }^{2}$

\begin{abstract}
Many researchers have addressed the importance of standards-based education; however, fewer studies have focused on the concept of student engagement as an essential component related to better education based on specific standards. To make education standardsbased, we should engage our students to help them meet or exceed the standards or achieve the Intended Learning Outcomes (ILOs). This article covers a brief review of student engagement, its common models in literature, and its different types (behavioral, emotional, and cognitive). It also discusses measurement of student engagement, its relationship to learning outcomes, and some strategies for improving it. We also proposed a model for standards-based education via integrating some strategies that improve student engagement types. It also gives some recommendations for students, teachers, and stakeholders on how to enhance student engagement based on the proposed model.
\end{abstract}

Keywords: standards-based education, student engagement, behavioral engagement, emotional engagement, cognitive engagement, learning outcomes.

1 Lecturer of Educational Psychology, College of Education, South Valley ${ }^{1}$ University, Qena, Egypt.

2 Professor of Educational Psychology, College of Education and Human ${ }^{2}$ Development, University of Minnesota, USA 
A Proposed Model for Student Engagement and Standards-based

\section{Education}

Dr. Mohammed Abdelhady Abdelsamea ${ }^{3}$

Prof. Dr. William M. Bart ${ }^{4}$

\section{Introduction}

Educational institutions have recently done their best to deliver standards-based education. In education, standards means what students should know and be able to do in each school subject. When education becomes standards-based, students show great mastery of the intended learning outcomes. However, how can education becomes standards-based without engaging students fully in the educational process? To ensure standards-based education, however, teachers, faculty, and stakeholders should work hard to engage students in the learning environment. In brief, student engagement supports meeting or exceeding the standards and consequently achieving standards-based education. In the context of the current article, student engagement is the focus via employing some strategies that help engage students and achieve standards-based education. In the next few sections, we addressed some definitions of student engagement, some common models, types and indicators, measurement, relationship to learning outcomes, some strategies for improvement, the proposed model of student engagement and

1 Lecturer of Educational Psychology, College of Education, South Valley ${ }^{3}$ University, Qena, Egypt.

2 Professor of Educational Psychology, College of Education and Human 4 Development, University of Minnesota, USA

(2): الدجة المصرية للاراسات النفسية - العدد 90 المجلد السادس والعشرون - يناير 2016ــ 
standards-based education, and some recommendations based on the proposed model.

\section{Definitions of Student Engagement}

Finn and Zimmer (2012) stated, "student engagement was conceptualized in the 1980s as a way to understand and reduce student boredom, alienation, and dropping out" (p. 99). Thus, researchers have proposed many definitions for student engagement. It is "student's psychological investment in and effort directed toward learning, understanding, or mastering the knowledge, skills, or crafts that academic work is intended to promote" (Newmann, 1992, p.12). Appleton, Christenson, Kim, and Reschly (2006) defined it as the active participation of students in educational tasks that enhances learning outcomes. Jones (2009) also defined it as the extent to which students are motivated, committed to learning, initiative, and communicative with their peers. Harper and Quaye (2009) added that student engagement is the students' active participation in the educational practices whether inside or outside the classroom. These practices result in measurable learning outcomes. Axelson and Flick (2011) noted that student engagement is the effective behaviors of learners in implementing the academic tasks. According to Walker (2011), it refers to the effective use of the cognitive and metacognitive strategies required for learning. In addition, Zepke (2013) indicated that student engagement is the effective partnership between professors and students in higher education institutions. This partnership achieves quality of learning.

المجلة المصرية للاراسات النفسية العدد 90- المجلد السادس والعشرون - يناير2016=ـح=(3)= 
It can be noted from the previous definitions that student engagement involves important learning behaviors such as commitment, motivation, participation, partnership and so on. It also involves some affective components such as partnership that achieves better cooperation in learning situations. Finally, it involves some cognitive and metacognitive strategies such as planning and monitoring comprehension.

\section{Models of Student Engagement}

Since the 1980s, various researchers have proposed some models of student engagement. In the next section, we describe briefly some of the most common models as follows:

\section{The participation-identification model (Finn, 1989):}

According to Voelkl (2012), Finn proposed one of the earliest models of student engagement in 1989 as shown in Figure 1:

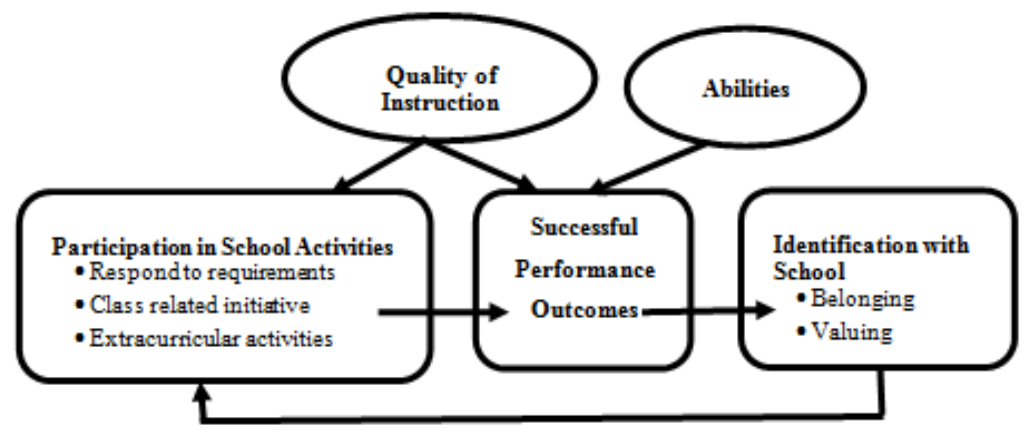

Figure 1. Participation-identification model adapted from Finn and Zimmer (2012, p. 101)

This model includes two components: participation and identification. Participation refers to behaviors that help students engage in learning activities and consequently completing the academic tasks. Identification refers to students' attitudes towards school especially belongingness and valuing. Thus, it includes the

(4): الدجلة المصرية للدراسات النفسية - العدد 90 المجلد الساس والعشرون - يناير 2016ــ 
behavioral (participation) and emotional (identification) components of student engagement. This model asserts the role of participation in supporting successful performance and positive attitudes towards school such as sense of belonging and valuing. These positive attitudes leads back to more participation in class and school activities.

\section{The four components model (Appleton et al. 2006):}

In 2006, Appleton et al. proposed the four components model of student engagement, namely, academic, behavioral, psychological, and cognitive components. This model confirms the role of contextual factors in student engagement such as family, peers, and schools. Families support learners academically and motivationally. Peers help one another through cooperation in school projects and shared values. Schools help learners via providing supportive learning environment, enrichment activities, and mental health programs. Thus, these contextual factors helps students engage actively in the learning environment and therefore achieve the academic, social, and affective learning outcomes.

\section{The basic model (M. A. Lawson \& Lawson, 2013):}

In 2013, M. A. Lawson and Lawson proposed the basic model of student engagement as shown in Figure 2:

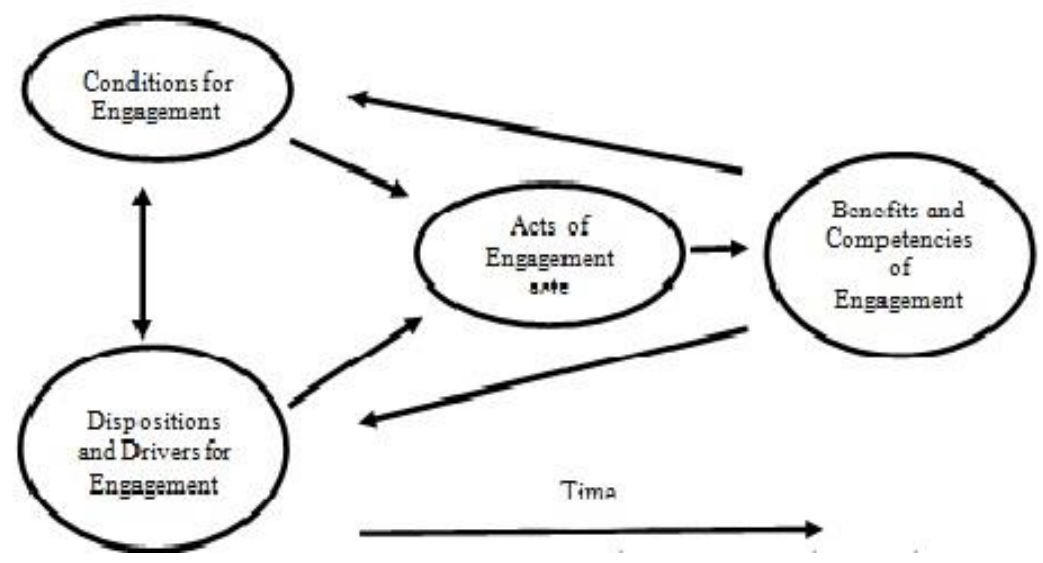

Figure 2. The basic model adapted from M. A. Lawson and Lawson (2013, p. 443) 
This model involves four main components, namely, conditions, dispositions, acts, and benefits of student engagement. Conditions and dispositions for engagement refer to the various factors such as school climate that affect students' actions for engagement. Acts of engagement refer to the various learning behaviors resulting from being engaged in the learning environment. Benefits of engagement refer to the effects of engagement on learning outcomes. To sum up, the three above models of student engagement share the same fact that is achieving better learning outcomes.

\section{Types and Indicators of Student Engagement}

Although researchers have proposed different definitions for student engagement, many of them agree that it is a multidimensional construct (Arballo, 2011; Darensbourg, 2011; Fischer, 2010; Fredricks, Blumenfeld, \& Paris, 2004; Mansour, 2015; Martin, 2012; Shernoff, 2013; Wolters \& Taylor, 2012). The most common types of student engagement are the behavioral, emotional, and cognitive types.

According to Pannozzo (2005), behavioral engagement refers to students' active participation in academic and social activities. Mccormick and Plucker (2013) defined it as the observable activities of students such as attendance, participation, and punctual assignment completion. The indicators of behavioral engagement include all effective learning behaviors such as persistence, efforts in class activities, commitment, participation in class and school activities, assignment completion, and instructions following.

Emotional engagement is related to the affective aspects of the learning environment. Appleton et al. (2006) view emotional engagement as students' sense of belonging and good relationships with peers and professors. According to Videen (2009), it refers to students' sense of identification and mutual respect between students and professors. Uden, Ritzen, and Pieters (2013) noted that indicators of emotional engagement include sense of belonging, safety, enjoyment, and respect within the university context. In brief, emotional engagement focuses essentially on the relationships among students on the one hand, and between students and their teachers or professors on the other.

Walker, Greene, and Mansell (2006) defined cognitive engagement as

(6)ـ الاجلة المصرية للاراسات النفسية - العدد 90 المجلد السادس والعشرون - يناير 2016ـــ 
the information processing strategies employed by students in completing academic tasks. According to Barnett (2012), it is the cognitive and metacognitive strategies such as rehearsal, elaboration, note taking, and organization of information. Lovelace, Reschly, Appleton, and Lutz (2014) stated that indicators of cognitive engagement include doing more than what is required, doing challenging tasks, managing distractors, and questioning of content.

\section{Measuring Student Engagement}

As a multidimensional construct, some researchers have proposed various measurement efforts in the educational and psychological literature. Some of these efforts have focused on measuring specific types of student engagement (Appleton et al., 2006), while others have constructed instruments for the most three common types: behavioral, emotional, and cognitive (Carle, Jaffe, Vaughan, \& Eder, 2009). Other studies have measured it in a specific school course (Handelsman, Briggswa, Sullivan, \& Towler, 2005). In the age of modern technology and wide spread of online courses, some researchers have tried to construct measurement instruments for online course engagement (Coates, 2006). In addition, many foreign universities administer the National Survey of Student Engagement (NSSE) every year. The results of this survey are regarded as indicators of student engagement in the learning environment and therefore the quality of learning outcomes. Generally speaking, measuring student engagement is one of the most necessary practices that should be done by educational institutions as an indicator for delivering the intended learning outcomes or standards-based education.

\section{Student Engagement and Learning Outcomes}

Researchers and educators have emphasized the effective contribution of student engagement in achieving better learning outcomes and therefore standards-based education. For instance, Carini, Kuh, and Klein (2004, April) surveyed 1058 university students and confirmed the linkage between their engagement and learning outcomes. Similarly, Coates (2005) indicated that student engagement is essentially related to the quality of learning outcomes. In addition, Furlong and Christenson (2008) illustrated that the importance of student engagement lies in its contributions in the educational reform initiatives. Additionally, Sbrocco (2009) noted that

المجلة المصرية للدراسات النفسية العدد 90- المجلد العادس والعشرون - يناير2016=ـ=(7)= 
increasing student engagement resulted in increasing learning outcomes. It also resulted in helping students be productive members in their communities. Metzger (2011) emphasized the role of student engagement in the academic achievement of adolescents. Additionally, $\mathrm{Hu}$ and Wolniak (2013) noted that student engagement is an integral part in standards-based education. It also affects the intended learning outcomes. In his study in the United States, Lee (2014) surveyed 3268 middle school students and found that student engagement and learning outcomes were highly correlated, especially in reading. Hospel and Galand (2016) indicated the importance of student engagement in achieving better learning.

We can note from the above-mentioned results of studies conducted to investigate the linkage between student engagement and learning outcomes that engaged students do their best via exerting much effort to better complete the assigned academic tasks. They try to participate actively in all school activities and be involved in the cognitive strategies required for learning. Generally speaking, student engagement is indispensable for achieving better learning outcomes and consequently achieving standards-based education.

\section{Strategies for Improving Student Engagement}

Student engagement, as noted, is an important component for delivering better learning outcomes and standards-based education. Thus, researchers have proposed various strategies for improving it. Zepke and Leach (2010) proposed 10 strategies for improving student engagement as follows:

\section{Enhance students' self-belief}

When students have high self-beliefs on their abilities, they adopt learning goals, see challenges as opportunities for learning, and therefore try hard to engage themselves in the learning task.

\section{Enable students to work autonomously and enjoy learning relationships with others}

Helping students learn independently makes them be self-confident and consequently highly engaged in learning activities. Similarly, when students enjoy learning relationships with one another, they become emotionally engaged and therefore do their best for better understanding and learning. 


\section{Recognize that teaching and teachers are central to student} engagement

Teachers have an effective role in engaging their students so they should adopt teaching strategies that engage students such as supporting challenging learning tasks, activating office hours for effective discussions with students, and demanding high standards for learning. Weaver and Wilding (2013) added that teachers play an effective role in engaging students via reducing their stress, building a positive emotional environment, and providing learning tasks that employ higher levels of cognition.

\section{Create learning that is active, collaborative and fosters learning relationships}

During lesson or lecture planning, teachers should make the learning atmosphere warm. It should call for active learning and positive relationships among peers. This makes students love the learning environment that in turn helps them be emotionally engaged learners.

5. Create educational experiences for students that are challenging, enriching, and extend their academic abilities

Similarly, teachers should create enriching educational experiences, challenging learning tasks, activities, and workshops that improve students' academic abilities. If students feel that their academic abilities are improved, they will be more engaged in the learning environment.

\section{Ensure institutional cultures are welcoming to students from diverse backgrounds}

Students enroll in schools or college from diverse backgrounds. The successful educational institution should provide a welcoming atmosphere for all students regardless of their backgrounds whether rural or urban.

\section{Invest in a variety of support services}

Educational institution should have supportive learning environments or provide various services required for better learning. Some of these services include academic, counselling, and healthy support.

\section{Adapt to change student expectations}

Educational institutions should regularly revise their policy and regulations to make sure they meet students' expectations.

المجلة المصرية للدراسات النفسية العدد 90- المجلد السادس والعشرون - يناير2016=عِ(9)= 
Stakeholders should consider students' feedbacks and change educational polices accordingly simply because students are main partners in the learning environment. When students feel that the school or college meet their expectations, they do their best to meet or exceed the standards.

\section{Enable students to become active citizens}

One of the most important objectives of education is to prepare an active citizen who helps in the progress of society. This happens if courses are related to or focus on the needs of these societies. When students study courses related to requirements of societies, they help solve the problem encountered and consequently be active citizens.

\section{Enable students to develop their social and cultural capital}

One of the major objectives of schools or colleges is to help students develop their social and cultural capital required for engagement such as communication skills and.

Tanner (2013) added some strategies that help engage students in learning. Some of these strategies include allowing students to write reflectively, monitoring their participation, using active learning strategies, collecting assessment evidences, and giving feedbacks. These practices are essential for creating engaging learning environment.

\section{The Proposed Model of Student Engagement and Standards- based Education}

One of the main aims of this article is to provide a greater insight in terms of the relationship between student engagement and standardsbased education via a proposed model based on the importance of student engagement and the strategies discussed earlier. The proposed model includes three strategies for improving each type of student engagement. Improving the types of student engagement results in increasing students' academic efforts for meeting or exceeding the standards and therefore achieving standards-based education.

(10) الجلة المصرية للاراسات النفسية - العدد 90 المجلد السادس والعشرون - يناير 2016ـي 
The proposed model is shown in Figure 3:

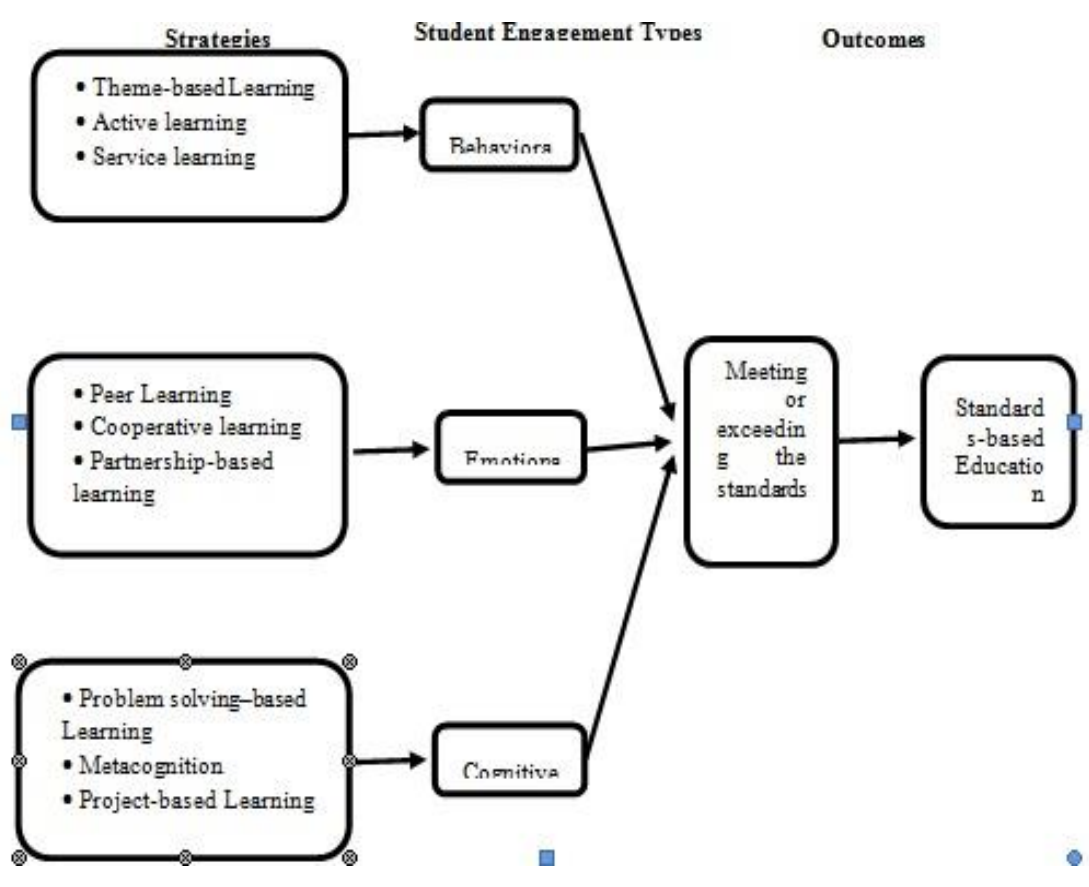

Figure 3. The proposed model of student engagement and standardsbased education

As shown in Figure 3, these strategies include:

\section{Theme-based Learning}

In theme-based learning communities, students have opportunities to choose among available academic tasks based on their vocational preference. This strategy integrates the academic content with the vocational implications available (National Research Council, 2003). This strategy improves students' ability to attend and follow instructions and hence improving their behavioral engagement.

\section{Active Learning}

Active learning is exerting much effort in learning situations or activities. It depends essentially on learners' active roles in learning. Barkley (2010) indicted that active learning is not only dividing students into small groups but also participating actively to finish the 
learning task and achieve better learning outcomes. Thus, it contributes much in improving behavioral engagement of students.

\section{Service Learning}

Service learning develop students' experiences as well as their academic and social competencies. It focuses on linking the academic programs with students' interests in their societies (National Research Council, 2003). This makes students feel that what they study is related to their real life. Thus, they try to involve themselves much in service learning programs and be more engaged in the learning environment

\section{Peer Learning}

Peer learning involves sharing knowledge and skills among peers. Peer tutoring is a special case of peer learning where senior students help juniors in their learning tasks and assignments. Peer learning makes students respect and appreciate the efforts of one another, which in turn makes them feel belongingness and consequently improving their emotional engagement.

\section{Cooperative Learning}

Like peer learning, cooperative learning supports effective communication among students, which helps students feel belongingness and mutual respect and increases their emotional engagement. Based on the results of his study among ninth graders, Young (2011) indicated that cooperative learning improves emotional engagement of students.

\section{Partnership-based Learning}

In partnership-based learning, teachers activate students' role in learning and make them real partners in the educational process as a whole. Students participate in setting learning objectives, selecting the target content, and determining the assessment methods. This makes them feel more confident and appreciated. They also feel that their interests are taken into consideration and their expectations are met. This increases students' attitudes towards the learning environment and improves their emotional engagement accordingly.

\section{Problem Solving-based Learning}

In problem-based learning, teachers make the learning situation as a problem that requires solution based on logical and scientific steps. Teachers serve as facilitators and guide students towards the solution

(12) الجلة المصرية للاراسات النفسية - العدد 90 المجلا السادس والعشرون - يناير 2016ـي 
of the problem. On the other hand, students think and reflect in the learning situation, which improves their cognitive engagement.

\section{Metacognition}

In recent years, researchers have addressed metacognition in many educational contexts. Metacognition means knowledge about knowledge. It includes two main components: knowledge about cognition and regulation of cognition. In learning situations, students should employ their metacognitive awareness in order to fully understand the assigned academic task. If students efficiently employ their metacognitive awareness, they monitor their academic progress, which results in increasing their cognitive engagement.

\section{Project-based Learning}

In project-based learning, teachers try to make the learning situation as an academic challenge or a project that should be accomplished based on the learners' critical thinking and decision-making skills. Students try hard to understand the basic elements of the academic challenge or the project. These skills improve cognitive engagement of students.

The proposed model included some strategies that improves each types of student engagement. After students become behaviorally, emotionally, and cognitively engaged, they do their best to meet or exceed the standards, which in turn results in achieving standardsbased education.

\section{Recommendations for Students, Teachers, and Stakeholders}

Based on the proposed model of student engagement and standardsbased education, there are some recommendations for students, teachers, and stakeholders as follows:

1. Students should do their best to actively engage themselves in the learning environment.

2. Students should provide teachers and stakeholders with their objective feedback on how much they are engaged learners.

3. Teachers should help students participate effectively in learning tasks and activities via adopting theme-based learning, active learning, and service learning strategies.

4. Teachers should help students respect one another and exchange opinions for mutual benefit. This improves students' emotional engagement.

5. Teachers should make the learning atmosphere warm and lovely to help students enjoy the learning environment and consequently be emotionally engaged. This can happen via adopting peer learning, cooperative learning, and partnership-based learning strategies.

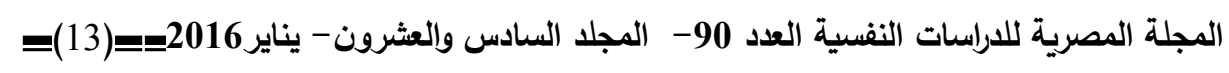


6. Teachers should help students be deeper and reflective thinkers in the learning environment to improve their cognitive engagement. This can happen via adopting problem-based learning, metacognition, and reflection strategies. They should make their teaching engaging or adopt Engagement-based Learning and Teaching (EBLT) approach.

7. Stakeholders should regularly measure student engagement since it is a key factor in achieving standards-based education.

8. Based on the results of this measurement, they change the educational and institutional policies to provide more opportunities for engaging students behaviorally, emotionally, and cognitively.

9. Stakeholders should provide students and teachers with all support services that increase their engagement.

10. Stakeholders should help students and teachers be more engaged for achieving standards-based education.

\section{Conclusion}

In the scope of this article, we addressed an important educational concept that is student engagement. In details, we discussed definitions of student engagement as well as its models, types, relationship to learning outcomes, improvement strategies. We also proposed a model that linked student engagement and standards-based education. The proposed model was illustrated graphically to facilitate its understanding and interpretation. The proposed model will enrich the educational and psychological literature in the areas of student engagement and standards-based education especially in the Arab Community. For instance, quality assurance units can make use of the model in increasing student engagement. In addition, measurement centers can employ this model to conduct research on measuring standards-based education. Based on the proposed model, we presented some recommendations for teachers and faculty for improving student engagement and therefore delivering standardsbased education. It will open new doors for research via conducting empirical research that focuses on achieving standards-based education. To sum up, teachers and stakeholders should work hard to improve student engagement to guarantee standards-based education.

(14) الاجلة المصرية للاراسات النفسية - العدد 90 المجلد السادس والعشرون - يناير 2016ـي 


\section{References}

Appleton, J. J., Christenson, S. L., Kim, D, \& Reschly, A. (2006). Measuring cognitive and psychological engagement: Validation of the student engagement instrument. Journal of School Psychology, 44(5), 427-445. doi: 10.1016/j.jsp.2006.04.002

Arballo, M. R. (2011). Factorial structure of engagement and its relationship to persistence: A study of adult secondary education students (Doctoral dissertation). Available from ProQuest Dissertations and Theses database. (UMI No. 3472517)

Axelson, R. D., \& Flick, A. (2011). Defining student engagement. Change, 43(1), 38-43. doi: 10.1080/00091383.2011.533096

Barkley, E. F. (2010). Student engagement techniques: A handbook for college faculty. San Francisco, CA: John Wiley \& Sons, Inc.

Barnett, P. A. (2012). High school students' academic buoyancy: Longitudinal changes in motivation, cognitive engagement, and affect in English and math (Doctoral dissertation). Available from ProQuest Dissertations and Theses database. (UMI No. 3494306)

Carini, R. M., Kuh, G. D., \& Klein, S. P. (2004, April). Student engagement and student learning: Testing the linkage. Paper session presented at the annual meeting of the American Educational Research Association, San Diego, CA, USA.

Carle, A. C., Jaffe, D., Vaughan, N. W., \& Eder, D. (2009). Psychometric properties of three new national surveys of student engagement based engagement scales: An item response theory analysis. Research in Higher Education, 50(8), 775-794. doi: 10.1007/s11162-009-9141-z

Coates, H. (2005). The value of student engagement for higher education quality assurance. Quality in Higher Education, 11(1), 25-36. doi: 10.1080/13538320500074915

Coates, H. (2006). Student engagement in campus-based and online education: University connections. New York: Routledge Taylor

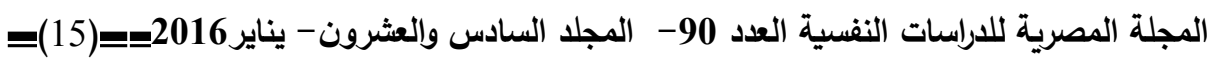


$\&$ Francis Group.

Darensbourg, A. L. (2011). Examining the academic achievement of black youth: The roles of social influence, academic values and behavioral engagement (Doctoral dissertation).Available from ProQuest Dissertations and Theses database. (UMI No. 3486082)

Finn, J. D., \& Zimmer, K. S. (2012). Student engagement: What is it? Why does it matter? In S. L. Christenson, A. L. Reschly, \& C. Wylie (Eds.), The handbook of research on student engagement. (pp.97131). New York: Springer Science. doi: 10.1007/978-1-46142018-7

Fischer, C. M. (2010). Where is the learning in small learning communities? Academic press, social support for learning, and academic engagement in small learning communities' classrooms (Doctoral dissertation). Available from ProQuest Dissertations and Theses database. (UMI No. 3441922)

Fredricks, J. A., Blumenfeld, P. C., \& Paris, A. H. (2004). School engagement: Potential of the concept, state of the evidence. Review of Educational Research, 74(1), 59-109. doi: $10.3102 / 00346543074001059$

Furlong, M. J., \& Christenson, S. L. (2008). Engaging students at school and with learning: A relevant construct for all students. Psychology in the Schools, 45(5), 365-368. doi: 10.1002/pits.20302

Handelsman, M. M., Briggswa, L., Sullivan, N., \& Towler, A. (2005). A measure of college student course Engagement. The Journal of Educational Research, 98(3), 184-192. doi: 10.3200/JOER.98.3.184-192

Harper, S. R., \& Quaye, S. J. (2009). Beyond sameness, with engagement and outcomes for all. In S. R. Harper, \& S. J. Quaye (Eds.), Student engagement in higher education: Theoretical perspectives and practical approaches for diverse populations. New York: Routledge Taylor \& Francis Group.

Hospel, V., \& Galand, B. (2016). Are both classroom autonomy support and structure equally important for students' engagement? A

(16) الاجلة المصرية للاراسات النفسية - العدد 90 المجلد السادس والعشرون - يناير 20162 
multilevel analysis. Learning and Instruction, 41, 1-10. doi: 10.1016/j.learninstruc.2015.09.001

Hu, S., \& Wolniak, G. C. (2013). College student engagement and early career earnings: Differences by gender, race/ethnicity, and academic preparation. The Review of Higher Education, 36(2), 211-233. doi: 10.1353/rhe.2013.0002

Jones, R. D. (2009). Student engagement: Teacher handbook. New York: International Center for Leadership in Education. Retrieved from http://fneii.ca/Student_20Engage_20handbook_20excerpt.pdf

Lawson, M. A., \& Lawson, H. A. (2013). New conceptual frameworks for student engagement research, policy, and practice. Review of Educational Research, 83(3), 432-479. doi: $10.3102 / 0034654313480891$

Lee, J. (2014). The relationship between student engagement and academic performance: Is it a myth or reality? The Journal of Educational Research, 107(3), 177-185. doi: 10.1080/00220671.2013.807491

Lovelace, M. D., Reschly, A. L., Appleton, J. J., \& Lutz, M. E. (2014). Concurrent and predictive validity of the student engagement instrument. Journal of Psychoeducational Assessment, 32(4), 112. doi: $10.1177 / 0734282914527548$

Mansour, H. F. (2015). Enhancing first year management students' engagement: An action research project to explore the use of the Essay Feedback Checklist (EFC). The International Journal of Management Education, 13(3). 2018-226. doi: 10.1016/j.ijme.2015.05.004

Martin, A. J. (2012). Part II commentary: Motivation and engagement Conceptual, operational and empirical clarity. In S. L. Christenson, A. L. Reschly, \& C. Wylie (Eds.), The handbook of research on student engagement. (pp.303-311). New York: Springer Science. doi: 10.1007/978-1-4614-2018-7

Mccormick, K. M., \& Plucker, J. A. (2013). Connecting student engagement to the academic and social needs of the gifted and talented students. In K. H. Kim, J. C. Kaufman, J. Baer, \& B. Sriraman

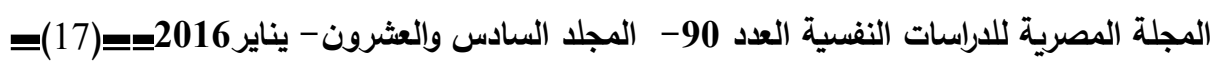


(Series Eds.), Creatively gifted students are not like other gifted students: Research, theory, and practice, Advances in Creativity and Giftedness Series, 5. (pp.121-136). Retrieved from https://www.sensepublishers.com/media/1528-creatively-gifted students-are-not-like-other-gifted-students.pdf

Metzger, I. W. (2011). Parenting profiles of academic and racial socialization: Associations with academic engagement perceptions of academic ability of African American Adolescents (Master Thesis). Available from ProQuest Dissertations and Theses database. (UMI No. 1503311)

National Research Council (2003). Engaging schools: Fostering high school students' motivation to learn. Washington, DC: The National Academic Press.

Newmann, F. M. (1992). Student engagement and achievement in American secondary schools. New York: Teachers College Press.

Pannozzo, J. M. (2005). Are patterns of behavioral and affective engagement related to dropout? (Doctoral dissertation). Available from ProQuest Dissertations and Theses database. (UMI No. 3179462)

Sbrocco, R. (2009). Student academic engagement and the academic achievement gap between black and white middle school students: Does engagement increase academic achievement? (Doctoral dissertation). Available from ProQuest Dissertations and Theses database. (UMI No. 3379401)

Shernoff, D. J. (2013). Optimal learning environments to promote student engagement: Advancing responsible adolescent development. New York: Springer Science. doi: 10.1007/978-1-4614-7089-2

Tanner, K. D. (2013). Structure matters: Twenty-one teaching strategies to promote student engagement and cultivate classroom equity. CBE: Life Sciences Education, 12, 322-331. doi: 10.1187/cbe. 13-06-0115

Uden, J. M., Ritzen, B., \& Pieters, J. M. (2013). I think I can engage my students: Teachers' perceptions of student engagement and their beliefs about being a teacher. Teaching and Teacher Education,

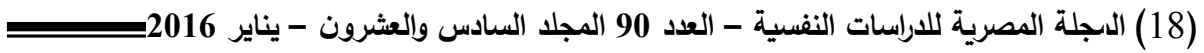


32, 43-54. doi: 10.1016/j.tate.2013.01.004

Videen, C. A. (2009). Longitudinal look at student achievement and psychological engagement (Doctoral dissertation). Available from ProQuest Dissertations and Theses database. (UMI No. 3389382)

Voelkl, K. E. (2012). School identification. In S. L. Christenson, A. L. Reschly, \& C. Wylie (Eds.), The handbook of research on student engagement. (pp.193-218). New York: Springer Science. doi: 10.1007/978-1-4614-2018-7

Walker, C. O., Greene, B. A., \& Mansell, R. A. (2006). Identification with academics, intrinsic/extrinsic motivation and self-efficacy as predictors of cognitive engagement. Learning and Individual Differences, 16(1), 1-12. doi: 10.1016/j.lindif.2005.06.004

Walker, C. T. (2011). Psychological climate for engagement and the role of leader behavior patterns in fostering employee engagement and performance behaviors (doctoral dissertation). Available from ProQuest Dissertations and Theses database. (UMI No. 3468070)

Weaver, L., \& Wilding, M. (2013). The dimensions of engaged teaching: A practical guide for educators. Bloomington, IN: Solution Tree Press.

Wolters, C. A., \& Taylor, D. J. (2012). A self-regulated learning perspective on student engagement. In S. L. Christenson, A. L. Reschly, \& C. Wylie (Eds.), The handbook of research on student engagement. (pp.635-651). New York: Springer Science. doi: 10.1007/978-14614-2018-7

Young, J. J. (2011). The impact of a cooperative learning environment on student engagement in ninth grade English (Master thesis). Available from ProQuest Dissertations and Theses database. (UMI No. 1502094)

Zepke, N. (2013). Threshold concepts and student engagement: Revisiting pedagogical content. Active Learning in Higher Education, 14(2), 97-107. doi: 10.1177/1469787413481127

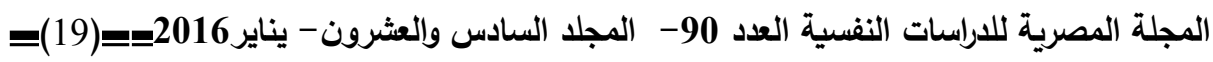


Zepke, N., \& Leach, L. (2010). Improving student engagement: Ten proposals for action. Active Learning in Higher Education, 11(3), 167-177. doi: $10.1177 / 1469787410379680$

\title{
نموذه مقترح لاندماه الطلاب والتعليم المبنى على المعايير
}

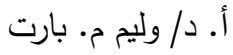

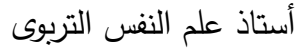 \\ كلية التربية والتمية البشرية \\ جامعة مينيسوتا \\ الولايات المتحدة الأمريكية
}

$$
\begin{aligned}
& \text { د/ محمد عبدالهادى عبدالسميع } \\
& \text { مدرس علم النفس التربوى } \\
& \text { كلية التربية بقنا } \\
& \text { جامعة جنوب الوادى } \\
& \text { جمهورية مصر العربية }
\end{aligned}
$$

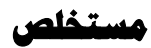

تتاول عديد من الباحثين أهية التعليم المبنى على المعايير ، ومع ذلك ركزت دراسات قليلة

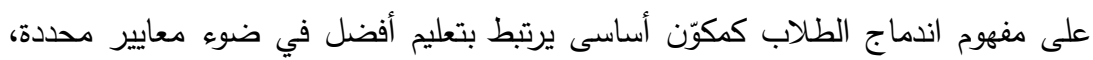

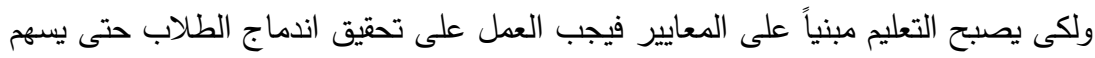

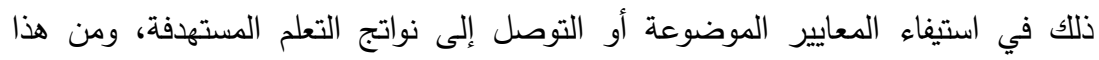
المنطلق تعرض هذه الدراسة النظرية مراجعة مختصرة لمفهوم اندماج الطلاب ونماذجه الثائعة في الأدبيات البحثية، وكذلك أنماطه (السلوكى، الوجدانى، المعرفى). وتتناول أيضاً

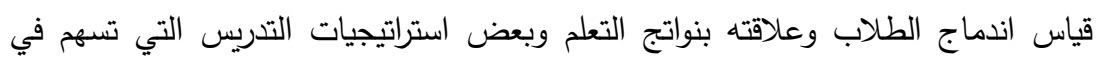

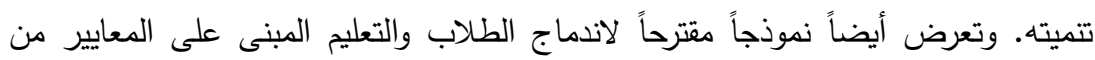

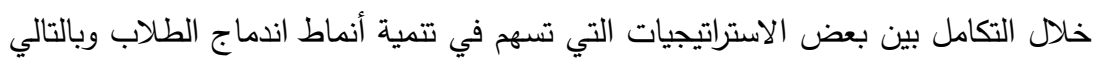

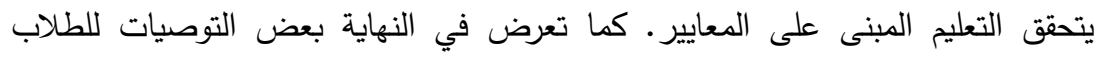

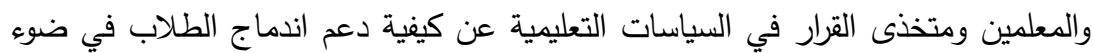

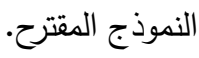

